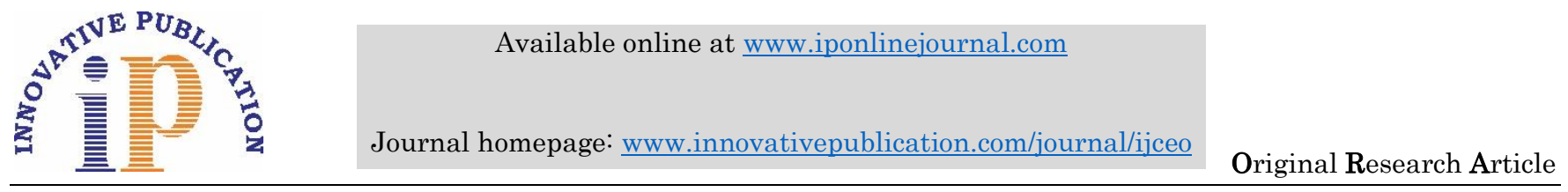

\title{
A clinical study of dacryocystitis
}

\section{Chaitra MC $^{*}$, S Pandu², MS Padmajothi ${ }^{3}$}

${ }^{\mathbf{1}}$ Assistant Professor, ${ }^{2}$ Professor and HOD, ${ }^{3}$ Professor, Dept. of Ophthalmology, ${ }^{1,3}$ Sri Devaraj Urs Academy of Higher Education and Research, Kolar, Karnataka, ${ }^{2}$ The Oxford Medical College, Hospital and Research Centre, Yadavanahalli, Karnataka, India

\section{Article Info}

Received: $23^{\text {rd }}$ December, 2018

Accepted: $23^{\text {rd }}$ May, 2019

Published Online: $9^{\text {th }}$ September, 2019

Keywords: Dacryocystitis, Dacryocystectomy, Dacryocystorhinostomy, Epiphora.

\begin{abstract}
Introduction: Dacryocystitis is an inflammation of the lacrimal sac and duct. Epiphora is the most common presentation of chronic dacryocystitis. This clinical study was undertaken to know the mode of presentation of dacryocystitis, spectrum of pathogens and the histopathological picture in chronic dacryocystitis patients who underwent dacryocystectomy.

Materials and Methods: Studied the various modes of presentation of dacryocystitis cases in respect to their distribution of age, sex, occupation, socio economic status, laterality, presenting complaints, clinical types of dacryocystitis and bacteriological study. The patients with gross nasal pathology were excluded from the study.

Results: Out of 60 patients, chronic dacryocystitis were $46(76.7 \%)$, acute cases $8(13.3 \%)$ and congenital cases were 5(10\%). Most commonly seen between 41-50 years of age group and predominately in females $(71.7 \%)$, house wifes $25(42 \%)$, lower socioeconomic status $33(55 \%)$, dacryocystitis showed left sided affection $32(53.33 \%)$ more than right. The most common presenting complaint was epiphora in 38 patients $(63.3 \%)$ and common microorganisms were Staphylococcus aureus 24(40\%). Histopathological results showed $85.7 \%$ non-specific chronic dacryocystitis.

Conclusion: As the nasolacrimal obstructions are the initiating event in establishing infection, it is important to know about microbial organisms responsible for dacryocystitis as it is one of the predisposing factors for postoperative endophthalmitis.
\end{abstract}

\section{Introduction}

Dacryocystitis is an inflammation of the lacrimal sac and duct. It may be classified as congenital or acquired. Acquired dacryocystitis is of 2 forms: acute and chronic. The most common cause of epiphora $(87 \%)$ is chronic dacryocystitis. ${ }^{1}$ It occurs in all age groups, the mean age group being 60-70 years. ${ }^{2,3}$ Congenital dacryocystitis is caused due to the developmental obstruction of nasolacrimal duct by epithelial debris or a membranous occlusion of the lower third of nasolacrimal duct. In acute dacryocystitis patients complain of watering, pain followed by swelling in the lacrimal sac region with oedema spreading over the lower lid and cheek. In acute dacryocystitis the most commonly isolated organisms are Staphylococcus species. ${ }^{4}$ Chronic dacryocystitis may be caused due to congenital abnormality, chronic sinus disease, involutional stenosis, naso-orbital trauma, granulomatous diseases such as Sarcoidosis, Tuberculosis, Wegener's granulomatosis. Involutional stenosis affects women twice as frequently as men. ${ }^{3}$ Acquired nasolacrimal duct stenosis occurs from gradual thickening of facial bones in older age group. ${ }^{5}$ Inflammatory causes includes bacterial and viral. The complications of chronic dacryocystitis include unilateral conjunctivitis, corneal ulceration, scleral abscess, panophthalmitis, facial cellulitis, orbital cellulitis, septic meningitis, cavernous sinus thrombosis and brain abscess which may endanger the life of a person.

\section{Objectives}

To study the various modes of presentation of dacryocystitis, to define the spectrum of pathogens causing dacryocystitis and to analyze histopathological findings of chronic dacryocystitis, in patients who underwent dacryocystectomy.

\section{Materials and Methods}

The study on dacryocystitis was carried out in the department of Ophthalmology, M.V.J. Medical College \& Research Hospital, Hoskote, over a period of 2 years from November 2012- October 2014. A total of 60 clinically diagnosed cases of dacryocystitis attending Ophthalmology out-patient department were taken for the study. All Patients with dacryocystitis (acute, chronic and congenital) were included \& patients with dacryocystitis due to gross nasal pathology were excluded from this study. After taking informed consent, demographic details and detailed history were taken. Detailed routine clinical examination was done to know the nature of discharge, fullness in the lacrimal sac area, dye disappearance test, Jones fluorescein dye test, lacrimal syringing and other ocular examination were done

*Corresponding Author: Chaitra MC, Assistant Professor, Dept. of Ophthalmology, Sri Devaraj Urs Academy of Higher Education and Research, Kolar, Karnataka, India

Email: drchaitramc@gmail.com

http://doi.org/10.18231/j.ijceo.2019.067 
Table 1

\begin{tabular}{|l|c|c|c|c|c|c|c|c|}
\hline \multicolumn{1}{|c|}{ Bacteriological study } & \multicolumn{2}{|c|}{ Acute } & \multicolumn{2}{c|}{ Chronic } & \multicolumn{2}{c|}{ Congenital } & \multicolumn{2}{c|}{ Total } \\
\hline & No & $\mathbf{\%}$ & No & $\mathbf{\%}$ & No & $\mathbf{\%}$ & No & \% \\
\hline Staphylococcus aureus & 3 & 37.5 & 18 & 39.13 & 3 & 50 & 24 & 40 \\
\hline Staphylococcus epidermidis & - & - & 14 & 30.43 & - & - & 14 & 23.33 \\
\hline Streptococcus pneumoniae & - & - & 8 & 17.39 & - & - & 8 & 13.33 \\
\hline Pseudomonas aeruginosa & 4 & 50 & 2 & 4.35 & - & - & 6 & 10 \\
\hline No growth & 1 & 12.5 & 4 & 8.70 & 3 & 50 & 8 & 13.33 \\
\hline \multicolumn{1}{|c|}{ Total } & 8 & 100 & 46 & 100 & 6 & 100 & 60 & 100 \\
\hline
\end{tabular}

(Anterior segment and posterior segment evaluation). In all the cases, conjunctival swab from the lower fornix was sent for identification of the organism and its culture and sensitivity. I could do dacryocystography in few patients with chronic dacryocystitis and few others refused for various reasons. DCG was done in radiology department using radioopaque, urograffin dye (76\%) under the guidance of the radiologist.

Congenital dacryocystitis cases were advised topical antibiotics and massaging over the lacrimal apparatus area. Even after conservative management for more than 1 year if watering persisted probing was done under general anaesthesia. Acute dacryocystitis patients were treated with topical and systemic antibiotics, analgesics, hot fomentation. If sinus formation or fistula present then the pus was drained out. For chronic dacryocystitis patients elective surgery was planned and scheduled after relevant systemic investigation, ENT consultation, physician opinion regarding fitness for surgery and local anesthesia. In elderly patients \& patients with thick fibrosed sac with no sac lumen dacrocystectomy was performed and for young and middle aged patients with chronic dacryocystitis dacryocystorhinostomy was performed. Excised lacrimal sac was sent for histopathological examination.

\section{Results}

Out of 60 patients $30 \%$ of them belonged to age group 41 50 years (youngest being 6 months old and the oldest was 71 years). 43(72\%) were females and 17(28\%) were males.

Majority were house wifes $25(42 \%)$ followed by laborers 12(20\%), farmers 10(17\%), preschool children $6(10 \%)$, teacher $3(5 \%)$, businessman $2(3 \%)$ and student and attender 1 each (2\%). 33 patients $(55 \%)$ belong to lower socioeconomic status and 25 patients $(42 \%)$ belong to middle socioeconomic status and 2 patients belong to upper socioeconomic class.

In our series of patients, 32(53.33\%) had left sided affection, 23(38.33\%) had right sided affection and $5(8.33 \%)$ patients were bilaterally affected, hence showing that the left side is more affected than the right.

$38(63.3 \%)$ cases complained of epiphora, 9(15\%) epiphora with swelling, $7(11.7 \%)$ epiphora with discharge, and $6(10 \%)$ with redness. $46(76.7 \%)$ cases were chronic dacryocystitis, $8(13.3 \%)$ were acute dacryocystitis and 6 cases $(10 \%)$ were congenital dacryocystitis. Out of 52 cases of congenital and chronic dacryocystitis, $37(71.15 \%)$ are with complete block, $15(28.85 \%)$ with partial block and in that 30(57.69\%) patients had mucopurulent discharge and $22(42.31 \%)$ patients had clear fluid regurgitation.

In this study the commonest organism encountered was Staphylococcus aureus 24(40\%), followed by Staphylococcus epidermidis 14(23.3\%), Streptococcus pneumonia 8(13.3\%) and Pseudomonas aeruginosa 6(10\%). 8 cases $(13.3 \%)$ had no growth.

\section{Bacteriological study in each type of dacryocystitis}

Out of 46 chronic dacryocystitis cases, 21 patients underwent dacryocystectomy and the excised sac was sent for histopathological examination of which 18 cases $(85.7 \%)$ showed features consistent with non-specific chronic dacryocystitis and 3 cases $(14.3 \%)$ showed fibrotic features. In our case study, majority patients $49(81.67 \%)$ had no associated nasal pathology but 7 patients $(11.66 \%)$ had inferior hypertrophied turbinate and 4 patients (6.67\%) had deviated nasal septum.

\section{Discussion}

The present study shows highest incidence in 4th decade (30\%) \& more commonly found in females $(71.7 \%)$ which is similar to a study by Chaudhry IA et al., ${ }^{6}$ The relatively high incidence of disease on left side (53.3\%) correlates well with P. Shiva Reddy ${ }^{7}$ studies. Most of the females come from middle and lower income group. In our study the main presenting feature is epiphora $(55 \%)$ followed by epiphora with other discharge (20\%). Our study correlated well with studies by Jouko Hutikainen. $(76 \%)^{2}$ and P. Shiva $\operatorname{Reddy}(80 \%){ }^{7}$ Redness and stickiness of lids constituted $10 \%$ of cases in our study and more incidence was seen in Prof. P. Shiva Reddy studies ${ }^{7}$ (75\%). Chronic dacryocystitis without associated mucocoele or lacrimal abscess was the most frequently encountered clinical type $(76.7 \%)$ in our study similar to Sood. N.N ${ }^{8}$ statistics $(66 \%)$. The next common presentation was acute dacryocystitis (13.3\%). Congenital dacryocystitis was $10 \%$ in our study.

$18.3 \%$ of cases had nasal pathology which is comparable to Rajeev N. Bhale ${ }^{9}$ study showing (29\%). Hypertrophied turbinate was observed in $11.7 \%$ of total cases followed by DNS 6.7\%. In this study Staphylococcus aureus was the most common microorganism over all (40\%) and it was isolated in $39 \%$ of chronic dacryocystitis cases, $37 \%$ of acute dacryocystitis cases and $50 \%$ of congenital dacryocystitis cases. Coden et al study also reported staphylococcus species as the commonest organism cultured. This was followed by staphylococcus epidermidis 
$(23.3 \%)$ and all were isolated from chronic dacryocystitis cases. Pseudomonas aeruginosa constituted $10 \%$ over all but constituted $50 \%$ of acute dacryocystitis cases. $13.3 \%$ cases were sterile. This can be compared to Jouko Hartikainen ${ }^{2}$ (15.7\%), Umesh Bareja ${ }^{11}(82.5 \%)$ studies. No fungal isolates were seen.

The antimicrobial sensitivity pattern varies from community to community because of the emergence of resistant strains as a result of indiscriminate use of antibiotics.

The Gram-positive isolates were most sensitive to vancomycin $(100 \%)$, followed by tobramycin, linezolid and ofloxacin $(94.73 \%)$. Gram-positive organisms were least sensitive to ciprofloxacin $(76.31 \%)$ and penicillin $(10.52 \%)$.

The Gram-negative organism $\mathrm{P}$ aeruginosa was most sensitive to tobramycin, imipenem, gentamicin $(100 \%)$ followed by cefepime $(83.3 \%)$ and least sensitive to ciprofloxacin $(50 \%)$. In a study by Kuchar A et $\mathrm{al}^{12}$ of congenital dacryocystitis, ofloxacin and tetracycline turned out to be most effective $(84.9 \%)$ to all Gram-positive and Gram-negative isolates. These were followed by chloramphenicol (83.6\%), bacitracin, ciprofloxacin $(61.6 \%)$, and norfloxacin $(60.3 \%)$.

Ghose $\mathrm{S}$ et $\mathrm{al}^{13}$ showed that tobramycin (100\%) was the most effective single antibiotic against all organisms, followed by gentamicin (97\%) and vancomycin (97\%). In Usha $\mathrm{K}$ et $\mathrm{al}^{14}$ study, Gram-positive organisms exhibited a higher rate of sensitivity to chloramphenicol, vancomycin, and ofloxacin. Non granulomatous inflammation consistent with dacryocystitis in the most common diagnosis in our study $(85.7 \%)$ which correlated well with Anderson $\mathrm{NG}^{15}$ study $(85.1 \%)$ and Maureillo JA Jr study $(89 \%){ }^{16}$

\section{Conclusion}

The study of dacryocystitis is an interesting subject in clinical ophthalmology, because it being the common clinical entity encountered in routine ophthalmic practice and also an important cause of ocular morbidity in India. Therefore this subject needs an extensive research to solve the enigma for the etiology of dacryocystitis. Availability of a wide range of successful treatment modalities for all the clinical form of the disease is the most satisfying fact. DCR done for chronic dacryocystitis has a very high success rate. Though this disease exists in varied form etiologically, the patients can be relieved of an unpleasant epiphora. Prompt surgical treatment helps in prevention and management of complications of dacryocystitis.

\section{Source of Funding: None.}

\section{Conflict of Interest: None.}

\section{References}

1. Jacobs HB. Symptomatic epiphora. Br J Ophthalmol. 1959;43:415-34.

2. Hartikainen J, Lehtonen OP, Saari KM. Bacteriology of lacrimal duct obstruction in adults. Br J Ophthalmol 1997;81(1):37-40.

3. Duke-Elder S, MacFaul PA: Diseases of the lacrimal passages. System of Ophthalmology. CV Mosby: St Louis, 1974;674770.

4. Terrence P. O’brein. Periocular Infections. In: Mandell, Douglas, Bennet. Eds. Principles and Practice of Infectious Diseases. 5th ed. Newyork, Churchill Livingstone 2000: 12747.

5. Mallik SRK, Chatterjee DL. Dacryocystography of normal and disturbed lacrimal passage. Orient Arch Ophth. 1970;8:5.

6. Duke Elder S, MacFaul PA. Diseases of lacrimal passages. Chapter X.In: The Ocular Adnexa in System of Ophthalmology, Duke Elder S (ed).St. Louis: C V Mosby Company 1974;675-773.

7. Siva Reddy P. Bhaskara Reddy D: Dacryocystitis - A clinico pathological study. J Indian Med Assoc 1955;24:413-6.

8. Sodd.N.N. Chronic dacryocystitis: A Clinico bacteriological study. J All India Oph Soc. 15:107.

9. Rajeev N Bhale, Dacryocystitis- bacteriology study and its relation with nasal pathology. Ind J Oph 1988;4:35.

10. Coden DJ, Hornblass A, Haas BD, Clinical bacteriology of dacryocystitis in adults. Ophthal Plast. Reconstr Surg 1993;9(2):125-31.

11. Bareja U, Ghose S. Clinicobacteriological correlates of congenital dacryocystitis. Indian J Ophthalmol 1990;38:66-9.

12. Kuchar A, Lukas J, Steinkogler FJ. Bacteriology and antibiotic therapy in congenital nasolacrimal duct obstruction. Acta Ophthalmol Scand 2000;78:694-8.

13. Ghose S, Nayak N, Satpathy G. Current Microbial Correlates of the Eye and Nose in Dacryocystitis - Their Clinical Significance. AIOC Proc 2005:437-9.

14. Usha K. Spectrum and the Susceptibilities of Microbial Isolates in Cases of Congenital Nasolacrimal Duct Obstruction. JAAPOS 2006;10(5):469-72.

15. Anderson NG, Wojno TH, Grossniklaus HE., Clinicopathologic findings from lacrimal sac biopsy speicmens obtained from 377, 71dacryocystorhinostomy. Ophthalmol Plast Reconstr Surg 2003;19(3):173-6.

16. Mauriello JA Jr. Palydowycz S, De Luca J. Clinicopathologic study of lacrimal sac and nasal mucosa in 44 patients with complete acquired nasolacrimal duct obstruction. Ophthal Plast Recontr Surg 1992;8(1):13-21.

How to cite this article: Chaitra MC, Pandu S, Padmajothi MS, A clinical study of dacryocystitis. Indian J Clin Exp Ophthalmol 2019;5(3):279-81. 